\title{
선진공여국의 ODA백서 기능과 역할 및 발전양상
}

\author{
KOICA ODA연구팀
}

\section{목 차}

I. 들어가며

1. 백서의 정의 및 수립목적

2. $\mathrm{OECD/DAC}$ 회원국의 $\mathrm{ODA}$ 백서 수립 현황

II. 주요 공여국 사례 분석

1. 영국

2. 일본

3. 아일랜드

4. 호주

III. 해외사례를 통해본 정책적 시사점

IV. 나가며

\section{I . 들어가며}

백서는 정부 정책을 명시하고 이를 대내외에 알리는 중요한 정책 문서로서 선진국뿐만 아니 라 우리나라 정부에서도 각기 다양한 분야의 정책에 대한 백서를 발간해오고 있다. $\mathrm{OECD} / \mathrm{DAC}$ 동료검토를 기점으로 최근 우리나라의 $\mathrm{ODA}$ 백서 발간에 대한 대내외적인 요구가 
높아짐에 따라, 동 보고서는 백서란 무엇이고 어떠한 기능이 있는지 살펴보고 나아가 주요 $\mathrm{OECD} / \mathrm{DAC}$ 선진공여국들의 백서 현황을 분석함으로써 우리나라 ODA백서 발간에 대한 교훈 및 시사점을 도출해 보고자 한다.

\section{1. 백서의 정의 및 수립목적1)}

백서는 각 정부부처에서 특정 사안에 대해 발간하는 공식 보고서로서, 여타 정부 발간 보고 서 중 최고 권위를 가진다. 또한 백서는 정부가 국내외 정치·경제·사회 등 각 분야에 대하여 현 상을 분석하고 미래를 전망하여 나온 정책을 국민에게 알릴 때에도 사용된다. 일부 학자들은 백서를 “참여적 민주주의의 도구로서, 정부 정책을 공식화하면서 그에 대한 의견을 수렴하기 위한 창구”로 정의한다. 즉 정책에 관한 정보를 전달함으로써 의회와 국민의 정책에 대한 이해 를 제고하는 한편, 정보 교환과 분석을 통해 논란의 여지가 있는 정책에 대해서는 미리 여론의 방향을 짐작해 볼 수 있게 하는 것이다.

따라서, 선진공여국들이 ODA백서를 수립하는 주된 이유는 자국의 개발협력 정책을 명확히 대내외적으로 알리고, 국내 유관부처 및 기관, 시민사회와 동일한 개발협력 비전과 목표를 공 유하기 위함에 있다. 나아가 자국 국민들을 대상으로 지구촌 빈곤퇴치와 지속가능한 개발 실 현을 위해 자국이 얼마나 국제사회에 기여하고 있으며 향후계획이 어떠한지 알림으로써, 국민 들의 개발협력 지지기반을 확보하는데 그 목적이 있다.

백서가 처음 발간된 영국에서 19세기 이전까지의 정부 출판물은 청서(Blue Book)가 주를 이루었다. 청서는 의회 보고를 위해 만들어진 파란색 표지의 정부 출판물을 지칭한다. 정부는 청서를 통해 의회의 법안 제정에 필요한 정보를 제공함과 동시에 정책의 방향성을 제시하여 의회의 정책적 판단을 지원한다. 청서는 의회뿐만 아니라 모든 국민을 대상으로 발간된 것이 지만, 당시 높은 문맹률 때문에 국민들의 이해와 지지 확보가 주된 목적은 아니었던 것으로 판 단된다.

그러다가 20세기 이후 정부조직이 다양하고 세분화됨에 따라 범부처적, 범의회적 공통의 관 심사가 늘어나기 시작했다. 이에 정부는 이러한 공통 사안에 대한, 그러나 청서보다는 짧고 간

1) 본 장은 KOICA에서 발주하고 이화여자대학교에서 수행하여 2013.9월초 발간 예정인 IODA 백서 수립 및 시행체계 사 례연구 $\lrcorner$ 의 제 2장을 재구성 함. 
결한 정부 보고서를 출간하기 시작했는데 이것이 백서(White Paper)이다. 이후 이러한 성격 의 공식 정부문서를 모두 백서로 명명해 오고 있는데, 경제에 대한 정부의 공식보고서를 경제 백서, 노동문제에 관한 것을 노동백서라고 호칭하는 것이 대표적 사례이다. 다시 말해, 청서가 의회에 제출하는 종합보고서라면 백서는 정부 전체의 입장을 대내외적으로 공식화하는 보고서 인 것이다.

그러나 백서의 내용이 '실제 정보’로 작성되지 않고 정부가 ‘알리고 싶은 정보'로 왜곡될 가 능성이 있다. 따라서 백서는 〈표-1〉과 같은 조건들을 갖추어야 한다.

\section{〈표 1〉백서의 조건}

\begin{tabular}{|c|c|}
\hline $\begin{array}{l}\text { 백서의 } \\
\text { 내용 }\end{array}$ & $\begin{array}{l}\mathrm{O} \text { 현 정부의 정책 및 전망 등 사실에 기반을 둔 정보일 것 } \\
\mathrm{O} \text { 선거 혹은 } \mathrm{PR} \text { 등 선전을 목적으로 하지 않을 것 }\end{array}$ \\
\hline $\begin{array}{c}\text { 백서의 } \\
\text { 발간 }\end{array}$ & $\begin{array}{l}\text { O 정례적으로 발간할 것 } \\
\text { ○ 국민과 입법부에 직접 공개할 것 } \\
\text { ○ 모든 이해관계자들 간 공청회 등을 통해 상호이해 강화를 위한 }\end{array}$ \\
\hline $\begin{array}{l}\text { 백서의 } \\
\text { 기능 }\end{array}$ & $\begin{array}{l}\text { O 정책 변화를 목적으로 하되, 특히 다음과 같은 경우에 수립할 것 } \\
\text { - 시간적 여유를 가지고 국민여론을 취합할 필요가 있을 때 } \\
\text { - 정책 성공을 위한 국민적 지지가 필요할 때 } \\
\text { - 일반적으로 정책결정과정에 참여하기 어려운 사회적 약자나 소수자들의 의 } \\
\text { 견을 반영해야 하는 정책을 수립할 때 } \\
\text { 입법-행정-시민사회-국민이 정책결정과정에 참여할 수 있는 채널로서의 역 } \\
\text { 할을 할 것 }\end{array}$ \\
\hline
\end{tabular}

\section{OECD/DAC 회원국의 ODA백서 수립 현황2)}

$\mathrm{OECD} / \mathrm{DAC}$ 회원국 중 $\mathrm{ODA}$ 백서를 수립한 국가는 노르웨이, 독일, 미국, 아일랜드, 영국, 일본, 캐나다, 호주 8개국이다. 그 외의 국가들은 ODA정책서 혹은 액션플랜(마스터플랜) 등 으로 백서를 대신하고 있다. ODA백서 수립 국가들은 백서 수립 배경과 목표에 따라 크게 [표 $-2]$ 와 같이 분류할 수 있다.

2) 본 장은 KOICA에서 발주하고 이화여자대학교에서 수행하여 2013.9월초 발간 예정인 「ODA 백서 수립 및 시행체계 사 례연구」의 제 2장을 재구성 함. 
〈표 2〉 국가별 ODA백서 수립 배경 및 목표

\begin{tabular}{|c|c|c|}
\hline 국가 & ODA백서 수립 배경 및 목표 & $\begin{array}{l}\text { 시점 및 } \\
\text { 주기 }\end{array}$ \\
\hline \multicolumn{3}{|c|}{$\begin{array}{l}\text { 1. 정책 프레임워크 수립 } \\
\text { - 개발협력 관련 제도개혁 또는 ODA 규모증대 등 공약을 계기 } \\
\text { - 범정부적 차원의 종합적이고 뚜렷한 개발원조 정책 및 전략 수립 필요 }\end{array}$} \\
\hline 영국 & $\begin{array}{l}\text { 1997년 노동당 정부 수립 이후, DFID 설립 등 개발협력 제도 및 정책 } \\
\text { 에 대한 전반적인 개혁이 이루어짐. 이를 위해 영국정부의 개발협력 } \\
\text { 정책목표 및 원칙을 새롭게 수립하고 ODA의 효과성 및 효율성을 개 } \\
\text { 선하기 위해 ODA백서를 수립함. }\end{array}$ & $\begin{array}{l}\text { 1997년, } \\
\text { 2000년, } \\
\text { 2006년, } \\
\text { 2009년 }\end{array}$ \\
\hline $\begin{array}{l}\text { 아일랜 } \\
\quad \text { 드 }\end{array}$ & $\begin{array}{l}\text { 2005년 아일랜드 수상이 MDGs 달성을 위해 2012년까지 ODA 규모 } \\
\text { 를 GNI의 0.7\%까지 확대하기로 약속. 이에 범정부적 차원의 개발원 } \\
\text { 조 정책·전략 수립 및 ODA 효과성 제고를 위해 ODA백서를 수립함. }\end{array}$ & 2006년 \\
\hline 호주 & $\begin{array}{l}\text { 2005년 호주 총리는 2010년까지 ODA를 40억 달러까지 2배로 확대 } \\
\text { 할 것으로 발표. 이에 증대되는 원조의 보다 효과적이고 효율적인 운 } \\
\text { 용을 위한 중장기적 ODA 정책 프레임워크로서 ODA백서를 수립함. }\end{array}$ & 2006년 \\
\hline 노르웨이 & $\begin{array}{l}\text { 노르웨이 정부의 주요 ODA 기조인 MDGs 달성 및 인권 증진에 대한 } \\
\mathrm{ODA} \text { 정책의 확고한 방향 및 목표 수립 및 이를 통한 원조의 효과성 } \\
\text { 과 효율성 증진을 위해 ODA백서를 수립함. }\end{array}$ & $\begin{array}{l}\text { 2004년, } \\
\text { 2009년 }\end{array}$ \\
\hline \multicolumn{3}{|c|}{$\begin{array}{l}\text { 2. 대국민 인지제고 } \\
\text { - 자국의 개발원조 정책과 방향에 대한 자국민의 인지 제고 }\end{array}$} \\
\hline 독일 & $\begin{array}{l}\text { 지구촌 빈곤 퇴치, 정의 실현, 기후 변화 대응, 평화 구축을 기조로 } \\
\text { 하는 독일 ODA에 대한 국민 인식 제고를 위해 ODA백서를 수립함. }\end{array}$ & $\begin{array}{l}\text { 2008년, } \\
\text { 2013년 }\end{array}$ \\
\hline 캐나다 & $\begin{array}{l}\text { ODA 정책 및 전략의 효과성 제고를 통한 국제사회의 MDGs 달성 및 } \\
\text { ODA에 대한 국민의 이해제고를 통한 세계시민 의식 강화를 위해 } \\
\text { ODA백서를 수립함. }\end{array}$ & 2005년 \\
\hline 일본 & $\begin{array}{l}\text { 1990년대 후반 각종 부정부패 관련 정치적 스캔들 및 장기적인 경제 } \\
\text { 불황 때문에 ODA 정책 및 사업집행에 대한 국내 여론이 악화됨. 이 } \\
\text { 에 일본 정부는 ODA에 대한 국민적 이해를 높이고, 이를 바탕으로 } \\
\text { 정책적 지지를 이끌어내고자 ODA 연간 보고서를 발간함. 2001년 이 } \\
\text { 후 일본 ODA 연간 보고서는 ODA백서로 이름을 바꾸어 발간됨. }\end{array}$ & $\begin{array}{l}\text { 2001년 } \\
\text { 이후 } \\
\text { 매년 } \\
\text { 발간 }\end{array}$ \\
\hline \multicolumn{3}{|l|}{ 3. 기타 } \\
\hline 미국 & $\begin{array}{l}\text { 미국 정부는 국가 안보와 개발의 연계성을 강화한 새로운 개발 프레 } \\
\text { 임워크의 수립을 목표로 ODA백서를 발간함. 미국 ODA백서는 비공 } \\
\text { 식적 정부 문서로서 원조정책과 안보, 외교 정책의 일관성을 강조하 } \\
\text { 고 국내 다양한 이해관계자들의 원활한 의견 공유를 목표로 함. }\end{array}$ & \\
\hline
\end{tabular}




\section{II . 주요 공여국 사례 분석3)}

이번 장에서는 주요 공여국의 백서 발간현황과 백서의 구성 및 내용뿐만 아니라 백서 발간 당시의 환경과 목적 및 기능, 백서 수립체계, 백서 수립 시 검토과정을 중심으로 사례를 분석 한다. 먼저 백서가 처음 발생되었으며 가장 모범적인 사례라 할 수 있는 영국과, 우리나라와 유사한 $\mathrm{ODA}$ 정책 및 체계를 갖추고 있는 일본, 그리고 최근 백서의 모범사례라고 할 수 있는 아일랜드를 분석하였다. 또한 동료심사에서 좋은 평가를 받은 호주를 중점적으로 분석하였다.

\section{1. 영국}

(1) 수립 배경 및 목적

영국 노동당 정부는 1997년 집권 후 정부구조 개편을 단행하면서, 원조 효과성 제고를 위해 대대적인 대외원조 제도 및 정책 개혁을 실시하였다. 먼저, 기존 대외 원조담당기관이었던 외 교부내 해외개발행정국 (Overseas Development Administration, ODA)을 중앙 정부부처 국 제개발부 (Department for International Development, DFID)로 독립 신설하였다. 이와 동 시에 첫 ODA백서인 "1997 세계 빈곤 퇴치: $21 \mathrm{C}$ 과제 (Eliminating World Poverty: A Challenge for the 21st Century)"를 발간하여, 영국 ODA 정책의 새로운 목표와 원칙을 발 표, 입법화를 추진하였다. 이후 2000년 “세계 빈곤층을 위한 세계화 (Making Globalization Work for the World's Poor)," 2006년 “빈곤층을 위한 거버넌스 (Making Governance Work for the Poor)"에 이어 2009년 제4차 백서인 “세계 빈곤 퇴치: 공동의 미래 구축 (Eliminating World Poverty: Building our Common Future)”을 발표하였다. 그러나 보수 당이 집권한 2010년 이후로는 “사업계획 (Business plans)”이 백서를 대신하고 있다.

백서는 영국의 최상위의 공식 정부 문서로서, 영국 정부의 명확한 ODA정책수립 및 의회의 입법 자료로서 발간된다. 다시 말해 정부의 전반적 $\mathrm{ODA}$ 정책방향을 국민과 의회에 명확히 전 달하는 것을 기본 목적으로 한다. 또한 백서 발간 과정에서 ODA정책실현을 위한 정부의 그동

3) 본 장의 영국, 일본, 아일랜드 부분은 KOICA에서 발주하고 이화여자대학교에서 수행하여 2013.9월초 발간 예정인 「 $\mathrm{ODA}$ 백서 수립 및 시행체계 사례연구 의 제 3장을 재구성 함. 
안의 성과를 국민과 정부 유관부처와 공유함으로써, 영국 원조와 개발협력에 대한 국민의 의 견을 수렴하고 인식을 제고하는 목적도 있다.

(2) 수립 체계

영국의 ODA백서는 DFID 주도로 이루어지며, 그 절차는 아래 [그림 1]과 같이 도식화 할 수 있다.

\section{〈그림 1〉 영국 ODA백서 수립 절차}

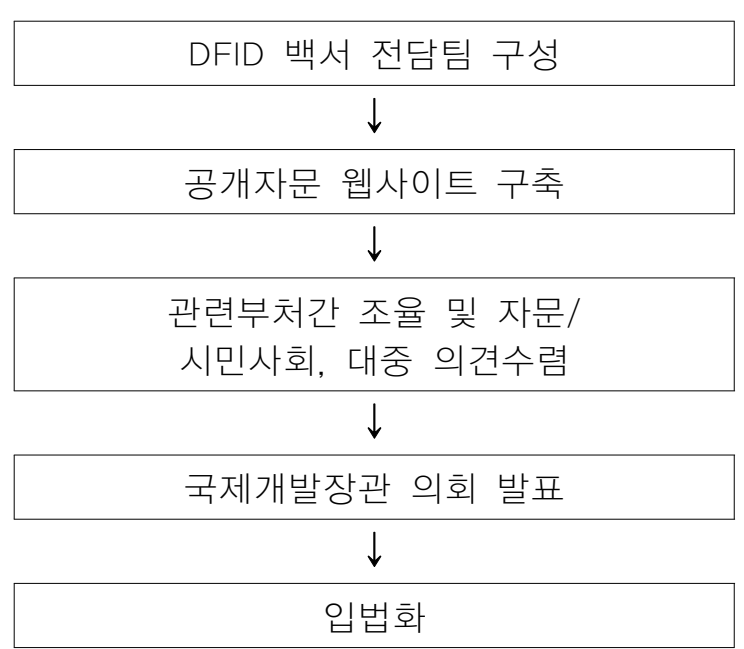

DFID는 백서 전담팀(White Paper Team)을 구성하여 백서수립 전반을 총괄한다. 백서 전 담팀은 약 십여 명의 고위급 직원으로 구성되며 약 6 개월 동안 활동한다. 전담팀은 백서 발간 에 앞서 공개자문 웹사이트를 구축하고 개발협력 전문가와 관계자는 물론 각계각층의 일반 대 중을 대상으로 백서에서 중점적으로 다루게 될 주제 및 이슈 관련 주요 질문들에 대한 의견을 받는다. 공개자문의 주요 질문은 경제 성장과 빈곤감소, 거버넌스와 개발, 기후 변화, 글로벌 거버넌스, 국제개발협력 시스템 개혁 등 백서에 담게 될 주제와 주요 이슈 및 국내외 현황 전 반을 다루고 있는데, 국제개발장관이 각 질문의 배경과 의미, 주요 관련 이슈들의 연계성에 대 한 간단한 자문문서(Consultation Document)를 발표하여 좀 더 실질적이고 구체적인 대중의 의견이 모아질 수 있게 한다. 이 모든 과정은 공개자문 웹사이트를 통해 이루어지며 이렇게 모 아진 의견들은 백서 전담팀이 취합·분석하여 그 결과를 백서 집필 시 반영한다. 
영국 백서 수립체계의 특이점은 위와 같이 외부를 대상으로 한 공개자문뿐만 아니라 정부 내부 부처의 자문과정을 거쳐, 관련부처 간 정책조율을 꾀한다는 것이다. 과거 노동당 집권 당 시에는 DFID를 포함한 영국 정부 내 모든 관련부처가 정책 및 협력 범위 조율을 위해 공공서 비스 협약(Public Service Agreement, PSA)을 체결하였다. 현재는 공동공약(Joint Commitment)을 통해 부처 간 정책을 조율하고 있으나 기본적으로는 국가안보회의(National Security Council)와 내각처(Cabinet Office)에서 정부 내 조정기능을 담당한다.

\section{(3) 구성 및 내용}

영국의 ODA백서는 세계빈곤퇴치와 같은 국제사회의 공약이 국내 정책에 반영되고 법률화 되는 것을 주요 목적으로 한다. 이를 위해서 국민과 의회를 효과적으로 설득하는 것이 중요하 기 때문에 백서에서는 글로벌 과제 및 이슈와 영국과의 연관성을 밝히고 이들 주제에 대한 구 체적 지원 목표 및 협력 방안을 설명하는 것을 중심으로 하고 있다. 나아가 백서발간을 통해 영국 정부는 새로운 글로벌 과제에 대한 국내 원조체계뿐만 아니라 국제적인 개발협력 프레임 워크의 저변을 넓히는데 기여해 왔다고 할 수 있다.

따라서, 영국 ODA백서의 주제는 각 발간 시점에 따라 변화 양상을 보이는데, 1997년 첫 $\mathrm{ODA}$ 백서 발간부터 현재까지의 주제 변화를 살펴보면 정책의 일관성, 세계화, 거버넌스, 취약 국, 지속가능한 개발 등 발간 당시 대두되고 있는 글로벌 과제에 대응하기 위한 영국개발원조 의 비전과 정책을 점검하고 향후 나아가야 할 방향을 제시하고 있다. 구체적으로는 1997년 첫 백서가 글로벌 문제해결을 위해 국제사회의 일원으로서 영국이 해야 할 '국제적 의무와 역할' 임을 강조한 반면, 2009 년 백서는 보다 다양한 글로벌 문제와 영국인의 삶과의 연관성을 강조 하며 원조가 '세계는 물론 영국을 돕는 길' 임을 강조하고 있다.

가장 최근에 발간된 2009년 ODA백서를 자세히 살펴보면, 1997년 1차 백서의 두 배 분량에 달하는 전체 155 페이지, 총 7 개의 장으로 구성되어 있다. 세부 목차 및 구성은 [표 3]과 같다. 
제 1장: 상호의존적인 세계의 빈곤 감소

- 영국과 새천년개발목표

- 다른 세계: 빈곤감소와 공통적 이해

- 공통의 명분

- 변화하는 세계에서의 개발협력

- 기회의 길

제 2장: 경제재건 활성화와 녹색성장

- 과제: 성장의 힘

- 경제침체에 대한 대응

- 회복력 있는 성장의 구축

- 장기적 성장으로의 이행

제 3장: 공동의 미래 유지

- 도전과제

- 국제적 노력

- 기후변화 대응 지식과 역량 구축

- 저탄소개발을 위한 투자 증대

- 개도국의 기후변화 적응 지원

- 개발 업무/관습의 변화

제 4장: 평화적인 국가와 사회 건설

- 분쟁과 취약성의 과제

- 새로운 접근: 평화와 국가건설의 우선시

- 기본사항으로서의 안보와 정의

- 경제적 기회 촉진과 자연 자원의 관리

- 범정부적 사업수행

- 평화 기반 구축을 위한 국제적 협력

제 5장: 경기침체에서도 개발협력 약속의 준수

- 새천년개발목표를 위한 자금지원

- 기본 서비스를 위한 자금지원

- 말라리아에 대한 향후 계획

- 역량 및 책임을 갖춘 국가에 대한 지원

- 새로운 교육 전략

- 모자보건 
제 6장: 국제시스템을 통한 협력

- 협력의 필요성

- UN을 통한 취약계층 지원

- $\mathrm{EU}$ 를 통한 글로벌 과제 지원

- 브래튼우즈 체제

- 지역개발은행을 통한 성장 지원

- 증가하는 인도주의적 수요의 충족

제 7장: 효과성 개선과 돈의 가치의 보장

- 새로운 과제, 새로운 접근법

- 효과성 및 돈의 가치의 보장

- 파트너 국가와의 협력방식의 변화

- 시민사회에의 새로운 접근법

- 영국 내 글로벌 상호의존성에 대한 이해 확립

- 민간분야와의 파트너십 강화

결론: 공동의 이익, 공동의 가치, 하나의 노력

첨부: 2008년 MDGs 달성현황

출처: 영국 2009 ODA백서

\section{(4) 역할 및 기능}

영국 $\mathrm{ODA}$ 백서의 주요 기능은 우선적으로 입법을 목적으로 하기 때문에 영국 국민을 주요 타깃으로 하고 있다. 따라서 백서를 발간하는 절차가 공개자문 과정을 통해 대중의 의견을 수 렴하고 동시에 정부의 정책적 비전과 어젠다를 알리는 채널의 역할을 한다. 이처럼 관련 부처 와 국민이 백서 수립과정에 참여할 수 있는 채널을 마련하여 궁극적으로 국민과 정부가 정책 결정에 기여할 수 있는 기회를 제공함으로써 입법과 인지제고를 동시에 추구하고 있다. 내용 적인 면에서도, 국내외 정세변화와 국제사회의 공약을 포함한 정책적 근거, 이에 대한 영국의 구체적 목표와 계획, 프로그램, 향후 공약에 대한 정보를 간결하고 명확한 어조로 전달하여 국 민의 이해와 지지를 꾀하고 있다. 


\section{2. 일본}

(1) 수립배경 및 목적

일본의 ODA백서는 ‘백서’라는 용어를 사용하고 있지는 않지만 1984년 발간된 “일본의 ODA (Japan's Official Development Assistance)"와 1994년부터 매년 발간된 “일본 ODA 연간보 고서 (Japan's ODA Annual Report)"가 독립된 정기간행물 형식으로 일본의 ODA정책을 소 개하고 그간의 활동을 정리한 공식문서라는 점에서 일본 ODA백서의 시초라고 할 수 있다. 특 히 “일본 ODA연보”는 일본이 1990년대 후반 각종 정치적 부정부패와 경제 불황을 겪으면서 정부 구조조정과 함께 $\mathrm{ODA}$ 사업 또한 축소되는 위기에 처했을 당시, 이를 해결하기 위해 일 본 외무성이 ODA정책에 대한 국민적 이해와 지지 확보를 목적으로 발간한 것이다. 그러다 2000년 이후 “일본 ODA연보”는 “ODA백서”로 명칭을 바꾸어 발간되고 있다.

\section{(2) 수립체계}

2002년 ODA헌장이 개정되면서 제3조에 외무장관을 일본 ODA 정책의 총괄자로 지정하고 제 5 조에 $\mathrm{ODA}$ 백서 매년 발간 및 내각 보고를 정부의 의무로 명시함으로써 백서발간의 법적인 근거를 마련하였다. 비록 ODA헌장이 법률로서의 구속력이 있는 규정은 아니지만 모든 ODA 관련 부처 및 기관들에게 정책 및 구조적인 가이드라인을 제시하는 중요한 법률적 근거가 되 고 있으며, 이를 바탕으로 일본 ODA백서는 매해 9월초 발간 계획을 수립하여 회계연도 종료 시점인 이듬해 3 월 즈음 발간되고 있다.

일본 $\mathrm{ODA}$ 백서 전담 조직으로 외무성 국제협력국 내 개발원조정책기획과 (Development Assistance Policy Planning Division)에 약 15 명 정도가 투입되어 백서의 기획과 집필, 출판 을 진행한다. 여기서 가장 주목할 점은 모든 과정이 철저히 외무성 내에서 이루어진다는 점이다.

백서 발간 절차를 살펴보면, 우선 앞서 살펴본 영국의 경우와는 다르게 이전 백서에 대한 공식적인 검토과정이나 시민사회를 비롯한 외부로부터의 검토와 의견수렴 과정이 없다. 일본 의 $\mathrm{ODA}$ 백서는 정책의 소개나 정책적 합의를 명시하고 변화를 이끌어내기 위한 목적으로 발 간되는 것이 아니기 때문에, 정치적 공약이나 목표를 담고 있지 않으며 때문에 이를 이행한 실 적 평가 및 피드백 과정이 필요하지 않다는 것이다. 또한 현재 일본의 전체 ODA예산의 $2 / 3$ 를 외무성과 JICA가 집행하고 있기 때문에 백서 수립과정에서 다른 10 여개 부처의 참여는 미미 
한 실정이다. 외무성에서 백서 초안을 작성하면 정부 간 내부 공지를 통해 부처들의 의견이나 내용에 대한 수정의견을 받는 절차를 거치긴 하지만, 백서 내용 전반을 좌우할 수 있는 검토 의견은 거의 없다. 다시 말해 일본의 ODA 백서는 외무성이 외부적 검토과정 없이 단독으로 작성하고 정부 내의 회람을 거쳐 내각에 보고 직후 출판하는 단순한 체계를 가지고 있다. 그러 나 여기서 주목해야할 것은 ODA헌장에 백서 수립의 주체와 보고 대상, 발간주기를 명확히 설 정함으로써 불필요한 혼선을 막고, 정치적인 상황이나 외부적인 이유로 인한 발간의 지연 또 는 취소를 방지하고 있는 점이다.

\section{(3) 구성 및 내용}

일본의 ODA백서의 주된 목적은 국민의 인식제고와 이를 통한 지지기반 확보에 있기 때문에 고등학생 정도의 독자가 이해할 수 있는 난이도로 작성되었으며, 사진·표·그래프 등 시각 자료 를 최대한 활용하여 높은 가독성을 보이고 있다. 내용면에서는 ODA관련 전문적인 정보나 정 책에 대한 논의 보다는 현재 국제사회의 동향과 이에 대한 일본정부의 입장, 일본 ODA 정책 에 대한 설명 및 그 당위성에 관한 내용들로 구성되어 있다.

일본 ODA 백서는 총 200여 페이지 정도 분량이지만 매년 새롭게 업데이트 되는 부분은 전 체가 아닌 일부(Part 1, 2에 해당하며 전체 분량의 $30 \%$ 정도)에 그친다. Part 1,2 는 일반 국민 이 ODA정책을 이해하는데 도움을 줄 수 있는 내용이나 MDGs를 비롯한 국제사회의 일본의 역할을 강조하는 주제를 매년 새로 선정하여 소개하고 있다. 예를 들어 2011년 백서에서는 "지 진의 극복 - ODA 및 세계와 우리의 결속 (Overcoming Earthquake - ODA and Our Bond with the World)"을 주제로 기술하여, 당시 동일본대지진으로 일본이 받았던 국제사회로부터 의 지원과 이전에 자국 $\mathrm{ODA}$ 활동을 연관시켜 세계와의 결속을 위한 ODA 활동의 정당성을 확 보하고자 했다. 2012년 백서의 경우 “국제협력 - 함께 나아가고 성장하기 (International Cooperation - Moving Forward and Growing Together)"를 주제로 경제 불황 속에서 제기 될 수 있는 ODA 활동에 대한 비판을 염두에 두고 동반성장을 강조함과 동시에, "회복력 있는 사회 건설 - 일본의 재해감소협력 (Building Resilient Societies - Japan's Disaster Reduction Cooperation)"이라는 주제로 지진과 재난 극복 경험을 바탕으로 한 국제 재해방지 분야에서의 일본 $\mathrm{ODA}$ 의 리더십을 강조하였다.

2012년 일본 ODA 백서의 구성을 살펴보면 총 4개 부분으로 나누어져 있으며, 세부 목차 및 구성은〈표 4〉와 같다. 
Part | 국제협력: 함께 나아가고 성장하기

O Chapter 1 함께 나아가기 위한 ODA

- Section 1 안정되고 풍요로우며 자유로운 국제사회 수립을 위한 ODA: 민주화와 국민화합을 위한 원조

- Section 2 일본에 대한 신뢰구축을 위한 ODA: 빈곤감소를 위한 성장

- Section 3 인적자원개발을 통한 성장의 여러 측면들

- Section 4 새로운 협력분야

- Section 5 모두가 참여하는 개도국에 대한 지원: 국제협력의 새로운 주체들

O Chapter 2 함께 성장하기 위한 ODA

- Section 1 개도국 내 민간자금 유입과 성장

- Section 2 중소기업의 해외진출과 개도국을 위한 ODA

- Section 3 인프라 수출을 통한 성장 기여

- Section 4 메콩, 인도, 아프리카: 풍부한 잠재력을 가진 지역

Part II 회복력 있는 사회 건설 - 일본의 재해감소협력

O Chapter 1 세계에 재해방지 전달

- Section 1 동일본대지진의 교훈 공유

- Section 2 2015년 제3차 세계방재회의 대비

- Section 3 지진 복구와 ODA

○ Chapter 2 방재협력 실무

- Section 1 ASEAN과의 협력

- Section 2 재난원조와 방재대책

- Section 3 방재와 재난 후 재건을 위한 국제기구와의 협력

- Section 4 도서국에서의 방재협력

Part III 회계연도 2011년의 ODA

O Chapter 1 일본의 ODA 지출현황

O Chapter 2 일본 ODA의 구체적 이니셔티브

- Section 1 ODA헌장의 기본정책과 관련 있는 이니셔티브

- Section 2 우선순위 이슈 별 현황

- Section 3 각 지역별 원조

- Section 4 원조집행 원칙의 운영현황

- Section 5 ODA 정책의 수립과 집행 


\section{(4) 역할 및 기능}

앞서 언급한대로 일본 ODA 백서는 정책을 수립하거나 새로운 중점분야를 공포하는 것이 아 닌, 국민의 이해증진과 지지기반 확보에 초점을 맞추어 발간되고 있다. 오히려 백서가 아닌 외 교청서에 $\mathrm{ODA}$ 관련 전문적이고 기술적인 내용이 담겨져 있으며, 백서는 일반인이 이해하기 쉬운 언어로 정리되어 있다. 청서의 내용이 백서에 삽입되면서 다양한 도표들이 삽입되고 기 본적인 개념의 변화를 도식화하여 설명하는 방식으로 기술되었으며, 정책서에 있었던 구체적 인 실행방안이나 계획은 축소/삭제되었다.

따라서 일본의 ODA백서는 백서를 대외적인 “홍보”의 목적으로 사용하는 대표적인 예라고 할 수 있으며, 실제 정부 홈페이지 접속 및 다운로드 기록을 보면 전체 정부부처를 통해서 $\mathrm{ODA}$ 백서의 조회건수 및 다운로드가 가장 많은 것으로 나타나 그 홍보효과가 크다고 할 수 있다. 특히 2012년 백서부터는 일부 고등학교 및 중학교 도서관에 열람용으로 비치 및 배포하 고 있어 미래세대의 개발협력 정책에 대한 지지기반 확보 기능도 수행하고 있다.

\section{3. 아일랜드}

(1) 원조 관련 정책4)

아일랜드의 정책문서는 백서를 최상위로 하여, 백서에서 중점 지원 대상인 분야별, 이슈별 로 모두 정책문서를 가지고 있다. 정책문서는 일반 정책문서, 가이드라인 등으로 구분되며, 각 분야별 정책 방향 및 실무에서의 적용을 위한 가이드라인 등으로 구성되어 있다. 백서가 전반 적인 아일랜드 원조 방향성을 제시한다면 Irish Aid's Operational Plan 2008-2012는 백서에 서 제시한 목적과 방향성에 따른 프로그램별 세부이행계획을 설명해준다. 아일랜드는 원조 운 영 계획 이외에도 분야별, 이슈별, 기획, 평가 등 사업 단계별로 세부 이행계획을 가지고 있다.

\section{(2) 백서 수립 배경 및 목적}

아일랜드의 백서는 국내외 경제침체 속에서 원조효과성과 책임성을 제고하기 위해 명확한

4) 저자 작성 
개발협력 정책 마련의 필요성이 증가됨에 2006년 처음으로 수립되었다. 아울러, 다른 나라의 사례와 유사하게 국내외 경제침체 속에서 해외원조에 대한 국민의 이해와 지지를 확보하기 위 한 것도 중요한 목적 중에 하나였다.

아일랜드의 백서는 발간 목적이나 발간 배경은 다른 나라의 경우와 유사하나 특이점은 관련 정부부처, 시민사회는 물론 개도국 파트너까지 포함하는 아일랜드 개발협력사업의 모든 이해 관계자들과의 장기간의 자문 및 협의과정에 의해서 이루어졌다는 점이다. 이러한 범정부적, 범이해관계자 검토 및 평가과정을 통해서 아일랜드 원조활동과 정책에 대한 국내의 이해 및 지지도뿐만 아니라 국외 이해관계자들의 이해도 및 인지도를 높이는데도 기여한 것으로 평가 받고 있다.

아일랜드는 2006년 첫 번째 원조백서(White Paper on Irish Aid) 수립 이후, 국내외 ODA 이외 개발활동 강조, 가속화된 국내 경기침체 등 국내외 상황변화에 따라 아일랜드 원조의 선 택과 집중, 성과제고를 가이드할 수 있는 정책서 수립의 필요성이 제기되어, 2013년 새로운 개발정책서인 “하나의 세상, 하나의 미래(One World, One Future)”를 발간하게 되었다. 이 정책서는 아일랜드 원조 목표와 중점분야를 중심으로 기존 원조백서에 비해 간략하고 명확하 게 정책 방향성을 담고 있으며 실제 기능상으로는 2 차 백서에 해당하나 기존 백서와의 혼란을 피하기 위해 백서로 칭해지지 않고 정책서의 명칭을 가지고 있다.

\section{(3) 수립 체계 및 절차}

아일랜드 원조 백서 발간은 외교무역부 산하의 Irish Aid가 주관한다. 집필은 Irish Aid 주 관이지만 집필 과정에서 아일랜드의 원조정책, 중점 협력 분야, 주요 수원국 등에 대한 각계 각층의 다양한 의견을 수렴하고 여러 채널의 자문을 적극적으로 접수한다. 2006년 백서 집필 기간은 2005년 4월부터 2006년 2월까지 총 18 개월이 소요되었는데 이중 공청회, 자문 등 의 견 수렴 기간이 초기 약 11 개월이 걸리는 등 백서상 주요정책에 대한 다양한 이해관계자들간 합의를 이루는데 심혈을 기울인 것을 볼 수 있다.

아일랜드 백서 발간 과정에서 또 다른 특이점은 2011년 신규 백서 발간시 2006년 백서에 대 한 평가 및 검토 과정을 거쳤다는 것이다. 백서 검토 및 평가과정은 차관 중심의 실무진이 주 관하였으며 검토 및 평가의 독립성과 객관성 유지를 위해 학계와 관련전문가 5 인으로 구성된 Irish Aid 전문가 자문단 그룹을 운영하였다. 자문단의 역할은 검토 및 평가과정이 투명하고 
효과적으로 시행되고 대중이 공개자문에 참여할 수 있도록 하며, 자문결과가 새로운 정책에 반영될 수 있도록 관리, 감독하는 역할을 수행한다. 2006년 수립된 백서에 대한 검토작업은 2006년 백서 수립후의 개선사항, 교훈, 성과 등에 초점을 맞추어 진행되었다.

백서 및 아일랜드 원조에 대한 대중의 자유로운 의견 개진 및 수렴을 위하여 추진되는 공개 자문은 전문가 자문단의 관리하에 아일랜드 주요 도시 및 학교를 대상으로 공청회와 워크샵, 협력대상 개도국에 대한 방문 등을 통해 실시되었다. 또한, 폭넓은 대중과 이해관계자들이 아 일랜드 원조에 대해 자유롭게 의견을 개진할 수 있게 하기 위해 간단한 질문지 형태로 작성된 자문 문서(Consultation Document)를 SNS를 통해 공개한다. 자문문서는 원조의 필요성, 원 조 효과성, 중점지역 분야와 국가 등에 대한 질문으로 구성되어 있다. 아일랜드는 의견 수렴자 는 국내 이해관계자와 대중을 넘어서 협력대상 개도국과 $\mathrm{UN}, \mathrm{OECD}, \mathrm{EU}$ 등 주요 국제기구까 지 포함하였다는 데서 타공여국과 차별성을 보인다.

\section{(4) 구성 및 내용}

아일랜드는 원조의 효과성과 정교한 원조수행체계 측면에서 자타가 공인하는 가장 모범적 인 국가중의 하나이다. DAC의 동료검토에서도 아일랜드는 가장 원조효과성이 높은 국가라고 평가하고 있으며, 아일랜드의 백서에서도 현재 아일랜드 원조의 높은 효과성을 유지시켜야 한 다고 밝히면서 자국의 원조에 대한 높은 자긍심을 보여주고 있다. 아일랜드의 백서는 내용면 에서나 수립체계 면에서나 모범사례로 평가받고 있기 때문에 향후 우리나라 백서가 궁극적으 로 지향해야 하는 방향성에 시사 하는바가 크다.

2006년 백서인 White Paper on Irish Aid는 아일랜드의 원조의 필요성과 이유 등 아일랜 드 원조의 철학과 비전을 명확하게 제시하고 있다. 백서의 1 장에서는 원조의 필요성 및 백서 의 필요성을 설명하고 있다. 주목할 점은 원조의 필요성을 정치적·경제적 차원에서의 국익을 원조를 통해서 추구하는 것은 잘못된 일임을 지적하면서 순수한 인도주의적 차원의 원조와 세 계시민으로서의 의무임을 매우 강조하고 있다. 아울러, 백서의 필요성에 대해서도 백서는 아 일랜드 개발협력의 중장기적 예산 배분의 기본적인 기준이 될 뿐만 아니라 개발과 관련된 모 든 정부정책의 최상위 정책적 틀임을 설명하면서 아일랜드 백서의 기능과 위상에 대해서도 명 확하게 제시하고 있다.

2장에서는 아일랜드 원조의 가장 큰 목표는 MDGs 달성, 아프리카, 중점지원분야(교육, 보 
건, Basic Needs, HIV/AIDS), 거버넌스 등에 있음을 설명하면서 각각의 비젼들에 대해 설명 하고 있다. 3장에서는 중점지원분야와 Cross-cutting 이슈인 평화, 치안, 인권, 젠더, 환경 및 무역 등 각각의 이슈별로 현재 개도국의 개발과제와 이에 대한 아일랜드 원조 지원방향, 각 분야 및 이슈별 특화된 이니셔티브 등에 대해서 설명하고 있다. 4장에서는 수원국 정부, 시민 사회, UN등 아일랜드 원조의 파트너십 구축 방향성을 설명하고 있으며 5장에서는 중점지원지 역인 아프리카를 중심으로 아프리카의 중요성과 해당지역에서의 원조 프로그램 및 성과들을 소개하고 있다. 6장은 개발에 대한 정부부처 정책일관성을 이루려는 아일랜드 정부의 노력과 성과를 소개하면서 개발은 원조나 개발협력뿐만 아니라 무역, 투자, 노동 등 모든 분야에서 협 력을 통해 이루어져야만 하는 사항임을 강조하고 있다. 7장은 아일랜드의 원조효과성 제고 계 획으로서 파리선언에서의 합의사항을 준수하고 평가를 강화하고 타공여국과 긴밀한 협력관계 를 통해 원조 성과와 품질을 제고할 것이라고 밝히고 있다. 8장은 아일랜드 원조에 국민들이 직접 참여할 수 있는 봉사단제도, 기업 및 시민사회가 직접 참여 가능한 그룹들에 대해서 소개 하면서 국민의 적극적인 참여를 독려하고 있다. 9 장은 2000 년대 이후 3 배 이상 급격하게 증가 한 아일랜드 원조의 효과적인 관리 방안에 대하여 설명하면서 아일랜드 원조에 대해 주기적인 평가 계획, 자문위원회 운영 계획, 분권화 계획 등을 소개하고 있다. 마지막으로 10 장은 ICT, 이주와 개발, 개발재원 등 새롭게 부각되고 있는 개발 이슈들을 소개하고 이에 대한 아일랜드 의 정책방향을 제시하고 있다.

2006년 백서가 150 여 페이지에 달하는 원조에 대한 종합적인 정책문서의 성격을 띠고 있는 반면, 2013년 발간된 개발정책서(One World, One Future)는 3개의 원조 목표와 6개의 중점 분야만을 집중적으로 소개하는 36페이지의 짧은 문서로 발간되었다. 2013년의 개발정책서는 백서의 최상위 정책문서로서의 역할 및 성과에 대해서 인정하면서도 새로운 개발이슈 및 과제 의 출현 등 변화하는 국내외 환경 변화에 부응할 필요성에서 동 정책서가 수립되었음을 설명 하고 있다(Irish Aid, 2013). 아울러, 새로운 개발정책서에서는 외교부 이외 정부부처 정책의 개발에 대한 일관성 제고를 강조하면서 동 정책서가 외교부 뿐만 아니라 모든 부처의 개발 관 련 활동에 대한 가이드라인 역할을 할 것임을 밝히고 있다. 이와 더불어, 아일랜드의 악화된 경제 상황등을 고려한 명확한 예산 배분 필요성을 설명하고 평화, 분쟁, 기후변화, 불평등, 개 발재원 등 새로운 개발 과제들에 대한 대응계획을 제시하고 있다.

개발정책서는 2006년 아일랜드 원조백서와 구성면에서도 다소 차이를 보인다. 1장은 2012 년에 행해진 백서에 대한 검토 과정, 검토 결과 및 교훈들을 소개하고 있다. 2 장은 백서 검토 결과 및 변화하는 국외 환경에 대한 대응방안으로서 3 개의 목표와 6 개의 중점분야를 제시하면 
서 각 목표 및 중점분야별 아일랜드 원조의 비젼 및 방향성을 위주로 설명하고 있다. 마지막 장에서는 아일랜드 원조 효과성 제고를 위한 전략 및 방안, 접근법을 종합적으로 소개하면서 정리하고 있다.

\section{아일랜드 원조의 3 대 중점 목표 및 6 개 중점 분야}

\section{$\square$ 중점 목표}

1) 기아 퇴치와 회복능력 강화(Reduced Hunger, Stronger Resilience)

2) 지속가능한 개발과 포용적 경제성장

(Sustainable Development, Inclusive economic growth)

3) 거버넌스 개선, 인권과 책임성 강화

(Better Governance, human rights and accountability)

\section{6 개 중점 분야}

1) 기아 퇴치

2) 취약국가

3) 기후변화와 개발

4) 무역과 경제성장

5) 필수적인 공공서비스

6) 인권과 책임성

\section{(5) 역할 및 기능}

백서는 아일랜드의 원조정책 중에서도 명실상부한 최상위정책으로서의 역할을 하고 있는 것으로 평가된다. DAC의 동료검토서는 아일랜드의 원조 백서에 대해서도 아일랜드 원조의 목 표와 비젼에 대한 뚜렷한 가이드라인으로서의 역할을 하고 있다고 평가하고 있으며, 하위정책 들이 백서에서 제시하는 원조목적과 지침들간 일관성을 이루고 있음을 설명하고 있다.

아울러, 아일랜드 백서의 수립 배경, 목적, 검토 및 평가과정을 살펴보면 백서는 범정부적, 전국가적으로 일관된 원조 사업 추진 방향성을 가이드해주기 위한 정책서임을 볼 수가 있다. 2006년 첫 번째 백서 수립시에도 백서는 아일랜드 원조의 방향성을 제공하기 위함이었음을 명시하고 있으며, 2013년 신규 백서에는 백서 수립 목적을 원조사업뿐만 아니라 아일랜드에서 이루어지는 모든 정부부처의 개발협력 활동의 가이드라인을 제시하기 위함이라고 밝히고 있 다. 백서를 통해서 아일랜드의 모든 원조사업이 일관된 방향으로 추진될 수 있도록 안내할 뿐 
만 아니라 백서 수립과정을 통해 아일랜드 원조의 방향성에 대한 국내외 대중과 이해 관계자 들간에 합의를 이뤼나가고 있음을 볼 수가 있다.

\section{4. 호주}

\section{(1) 원조 관련 정책}

호주의 원조정책은 2011년 발간된 An Effective Aid Program for Australia(이하 Effective Aid Program)가 가장 상위 단계의 정책서이며, 그 하위에 원조 중기 예산계획서인 (2013-2016) Australia's Comprehensive Aid Policy Framework(이하 CAPF)가 있으며, 그 외에 분야별 주제별 이행전략들을 가지고 있다. Effective Aid Program은 최상위의 정책으로 서 호주의 원조에 대한 가치관 및 호주 정부의 공약을 어떻게 실행할 것인지에 대한 방향성 위 주의 내용이라면 $\mathrm{CAPF}$ 는 4년간의 예산계획 및 그에 대한 이행계획들로 좀 더 세부적인 실행 전략에 가까워 최상위 정책서와 하위 전략들간 성격 구분이 비교적 명확하게 되어 있음을 알 수가 있다. 호주는 Effective Program과 CAPF등 전반적인 원조 정책 및 계획을 가이드하는 정책서와는 별도로 분야별, 이슈별, 국별 지원전략 및 평가 전략들을 수립하여 실제 사업 집행 및 추진에 참고하고 있다.

\section{(2) 백서 수립 배경}

2004년 인도네시아 쓰나미시 호주의 신속한 복구 지원 노력은 주변국의 경제사회적 상황에 대한 호주의 협력의 중요성과 역할에 대한 국내인식이 크게 증대되는 계기가 되었다. 아울러, 당시 비교적 안정된 국내 경제적 상황에서 주변국가에 대한 국제개발협력에 대한 공감대 형성 이 가능하였다. 이와 같이 한층 높아진 국제개발협력에 대한 국민적 인식을 바탕으로 2005년 9 월 호주 정부는 2010년까지 자국 ODA를 2 배인 40 억까지 증대할 계획을 발표하고 증대되는 원조의 효과적이고 효율적인 운용을 위해 백서 수립의 필요성이 대두되어 2006년 첫 번째 개 발백서인 “호주 원조: 성장과 안정을 도모(Australian Aid: Promoting Growth and Stability) 를 발간하였다.

백서에는 호주 원조의 목적을 개도국의 빈곤을 감소하고 지속가능한 발전을 이루고 호주의 국가안보 및 국익의 연장선상에서 아태지역 주변국가들의 평화와 번영을 이루기 위한 외교적 
수단임을 설명하고 있다. 아울러, 백서는 이러한 호주 원조의 목적을 향후 10 년간 어떻게 이룰 것인가에 대한 정책적 틀이며 AusAid뿐만 아니라 호주의 모든 원조에 적용됨을 설명하고 있다.

호주 정부는 백서의 서두에서 백서 수립 목적을 아래와 같이 밝히고 있다. 첫째로, 백서는 향후 10 년간의 호주 해외원조사업에 대한 포괄적인 계획을 제시한다. 또한, 백서는 지난 50 년 간 호주의 원조 수행경험 및 국제개발사회의 지식에 기반한 호주 정부 및 국민의 개발에 대한 가치를 보여준다. 둘째로, 백서는 개발효과성에 대한 연간보고서(Annual Review of Development Effectiveness)와 더불어 원조재원에 대한 납세자인 호주 국민들에게 호주 원조 의 계획과 성과에 대한 정보를 공유함으로써 국민들의 원조사업에 대한 이해와 공감을 얻고자 함을 강조하고 있다. 셋째로, 백서는 주변 지역의 개발과제 대한 호주 정부의 통합되고 조율된 대응전략이며 이를 통해 MDGs 달성에 대한 호주의 기여효과를 극대화시키고자 함이다.

이러한 호주의 백서는 2007년말 정권이 교체되고 호주 정부의 조직개편이 단행되면서 백서 의 기능 및 내용도 변화되어 2011년 7월 호주 정부는 새로운 호주 원조정책서인 "호주의 효과 적인 원조 프로그램-진정한 변화와 실질적인 성과(An Effective Aid Program for Australia: Making A real Difference-Delivering Real Results)를 수립했다. 새로운 정책 서는 증가하는 호주 개발원조의 보다 효율적인 운용과 빈곤극복에 대한 정책 초점을 강화하 며, 현재 백서를 대체해 호주 대외원조 정책 프레임워크로서 기능하고 있다.

\section{(3) 구성 및 내용}

2006년 White Paper는 호주가 왜 원조를 해야하고 2005년 호주 정부가 공약한 원조자금을 어떤 지역의 어느 분야에 쓸 것인지에 대한 내용에 초점이 맞추어져 있다면 2011년 Effective Aid Program은 변화된 제목에서도 알 수 있듯이 원조효과성 및 원조집행 효율성에 초점을 두 고 있다. 아울러, 원조 효과성 제고를 위해 개발 관련 정책내외에서의 정책간 일관성과 통합을 강조하고 있다. Effective Aid Program은 동 정책서에서 제시되는 내용이 호주 국민과 여러 관련된 정부부처 사이에 합의를 이루고 공감대가 형성된 내용임을 강조하며, 모든 원조는 동 정책서와 일관성을 유지해야 함을 강조하고 있다.

아울러, 2006년의 백서와 2011년의 Effective Program은 호주의 원조가 인도주의적 차원 에서의 세계 빈곤감소 및 세계시민으로서의 호주국민의 의무임과 동시에 주변 지역의 평화와 번영을 통해 호주의 번영과 국가안보를 지킬 수 있는 수단임을 실제적인 예시를 통해서 명확 
하게 설명함으로써 호주 국민에게 원조의 필요성에 대한 공감대와 지지를 얻으려는 노력을 하 고 있음을 볼 수가 있다.

또한, 중점지원 분야, 중점 지원국가 및 예산배분 계획에 대한 설명에서도 지원실적이나 향 후 계획보다는 중점지원 분야와 지원 국가를 선정하게 된 이유, 예산 배분 기준 및 원칙에 대 해서 주로 설명하고 있다. 예를 들어 아태지역을 중점지원 지역으로 선정하는 이유에 대해서 주변 지역으로서 호주의 국익과 안보에 가장 밀접하게 연결되어 있기 때문이라고 설명하며 호 주의 원조를 받은 한국과 중국이 현재 호주의 가장 큰 교역국으로 변화한 것을 실례로 들고 있 다. 예산 배분에 대한 기준으로는 빈곤인구가 가장 많은 국가, 호주 정부가 가장 크게 기여할 수 있는 국가, 호주 정부의 국익과 연결되는 국가 등 세 가지 기준을 제시하고 있다. 이러한 설명은 호주 정부의 원조정책을 국민에게 투명하게 공개하고 납득시키려는 목적에 중점을 둔 것으로 보인다.

2006년 백서의 구성을 보면 1장에서는 전반적인 원조의 필요성과 원조의 목적을 제시하고 있으며 2장에서는 국제개발 환경 및 과제들을 설명하고 있다. 3장에서 7 장까지는 1장과 2장의 호주 원조 목적과 국제 환경을 고려한, 호주의 원조 계획과 성과 제고를 위한 방향성을 위주로 기술되어 있다. 2011년의 개발정책서는 2010년말 추진된 호주 원조의 효과성에 대한 독립평가 (Independent Review of Aid Effectiveness) 결과를 바탕으로 내용이 구성되었다. 동 평가는 호주 원조 역사상 처음 행해진 종합적인 원조평가로서 39 개 정책제언사항을 도출하였는데 그 중에는 호주 원조의 정책총괄목표, 중점지원국 및 분야 조정, 원조 파트너십 강화, 원조 효과 성 및 성과평가 강화 및 투명성 제고 등이 포함되어 있다. 이에 따라, 2011년 정책서에는 이러 한 평가결과가 반영이 되어 원조 효과성 부분이 크게 강화되었으며, 중점 지원분야에 새롭게 등장한 글로벌 개발과제들인 식량안보, 민간부분 발전, 시민사회 강화, 거버넌스 등이 추가되 었다. 2011년 정책서에서는 원조효과성과 함께 원조 필요성, 호주 원조정책의 목적에 대한 항 목이 강화된 것을 볼 수 있다. 이것은 2007년 신정권의 ODA확대 공약으로 ODA예산 증대에 대해 국민의 지속적인 지지도를 확보하기 위한 것으로 판단된다.

\section{(4) 역할 및 기능}

호주 원조 백서 등 최상위 정책서는 전반적으로 호주의 원조 필요성에 대한 국민에 대한 설 득 및 정부의 원조 정책에 대해 국민에게 설득시키는 내용 위주로 구성 되어 있다. 그리하여 백서의 전반에 부문별 원조 정책에 대해 “왜”라는 물음에 대해 답을 하고 그 답에 대한 근거를 
제시하면서 해당 원조정책에 대한 당위성을 찾으려는 듯한 노력을 보이고 있다. 또한, 그러한 기술방식으로 인해서 $\mathrm{CAPF}$ 등 중기전략이 예산배분 계획, 성과지표 및 평가계획 등 구체적인 이행계획을 제시하는 것과는 뚜렷한 차별점을 보이고 있다.

또한, 백서에는 원조가 호주 자국의 외교적인 수단임을 솔직하게 인정하면서도 동 국익이 일반적으로 말하는 국가의 이기적인 이해가 아니고 타국가와의 공존과 상생을 의미함을 설명 하고 있다. 이것은 호주 정부가 백서를 통해 원조의 필요성 및 철학에 대한 국내의 다양한 견 해 및 논란에 대해 해명하고 일치된 방향으로 설득시키려는 노력을 하고 있음을 볼 수가 있다.

\section{III. 해외사례를 통해본 정책적 시사점}

타 공여국의 백서 수립 과정, 목적 및 내용을 보면 아래와 같은 공통점을 가지고 있다.

첫째, 백서의 역할이다. 백서는 공여국의 원조 철학, 원조 필요성 및 비전과 방향성을 위주로 구성이 되어 있으며, 자국 내의 원조 철학 및 필요성에 대한 다양한 의견을 공식선상에 끌어올 려 합의된 의견을 도출하여 제시하는 데에 중점을 두고 있다. 이를 위해 백서 수립 과정에서도 장기간에 걸쳐 자국의 원조 우선순위, 철학 및 목적에 대해서 관련 정부부처, 일반 대중, 전문

가 그룹 및 수원국의 의견까지도 접수하여 반영하고 있다. 이를 통해, 자국의 원조목적 및 비전 에 대해 전 국민적 공감대를 이루어나가고 있으며, 이러한 논의 및 합의결과는 백서에 반영되어 자국 내의 모든 개발협력사업의 가이드라인으로서의 정당성을 확보해주고 있음을 보여준다.

원조의 필요성에 대한 다양한 의견 및 해석이 분분한 우리나라의 상황을 고려할 때, 백서수 립은 그 과정을 통하여 한국의 원조 철학에 대한 다양한 의견들을 수렴하고 논의하는 기회를 제공하고 합의된 방향을 도출해주는 역할을 해야 할 것이다. 아울러, 정도의 차이는 있지만 대 부분의 공여국 백서가 자국의 원조 당위성에 대하여 인도주의적 목적 등 보편적이고 이상적인 이유뿐만 아니라 자국의 국내정치, 경제적 현실과 연계한 안보, 경제, 사회적 국익 추구를 위 함이라고 비교적 솔직하게 밝히고 있다는 점도 고려해야할 것이다. 즉 최근에 수정된 선진국 의 백서나 이에 준하는 정책서에는 원조의 필요성과 당위성 등에 대한 부분이 더욱 강화되었 고 원조의 필요성을 자국의 경제사회적인 현황과 연계하는 논조가 강해지고 있는데, 이러한 경향은 최근 세계 경제위기로 모든 국가들이 원조 예산의 확대에 대한 국내 논란에 직면해 있 
는 현실을 반영하고 있는 것으로 보인다.

현재 우리나라는 국제적인 위상 제고 및 경제정치적인 영향력 확대 등을 위해 ODA 예산을 대폭 증가할 필요성은 있으나, 악화된 국내외 경제상황과 대외원조에 대한 낮은 인식수준 등 으로 $\mathrm{ODA}$ 예산 확대에 대한 논란이 커질 것으로 예상된다. 따라서 원조 백서도 원조의 필요 성에 대해 천편일률적이고 상식적인 사유들만 제시하는 것이 아닌 우리나라의 경제, 정치 및 사회적 현실과 필요를 고려한 맥락에서의 원조의 당위성을 제시하여 이에 대한 국민의 공감대 와 지지를 끌어내는 실질적인 수단이 될 수 있도록 해야 할 것이다.

둘째, 원조 관련 정책 문서 내에서의 백서의 위상 및 타정책서와의 관계이다. 타정책서가 원조 사업 추진 방향, 중점분야, 지원 대상 국가들에 대한 세부적인 예산계획, 평가 지표 등 실행계획 위주로 구성된 것에 비해, 백서는 중점분야, 지원국가 등 타정책서와 동일한 주제 및 이슈에 대해서도 각국이 그러한 분야와 국가를 선정한 당위성 및 방향성에 중점을 두고 있다. 원조사업의 성과나 실적 등을 설명할 때에도 구체적인 통계 실적 등은 사례로서 간단하게 언 급될 뿐이며, 향후 이러한 성과를 원조정책에 어떻게 반영할 예정인지 방향성 위주로 제시되 어있다. 따라서, 현재 수립하고 있는 우리나라의 백서도 특정 원조정책 및 전략을 선택하게 된 배경, 근거 및 방향성 위주로 기술해 타 정책문서와 차별성을 보일 필요가 있을 것이다. 아울 러, 백서는 단순히 정부의 원조정책 및 계획을 국민과 공유하는 수준을 넘어 정부의 원조정책 수립 배경 및 사유를 좀 더 투명하게 공개하고 납득 시키려는 노력을 보여줌으로써 국민의 지 지와 신뢰를 얻는 수단으로서의 역할을 해야 할 것이다.

셋째로, 백서는 개발 이외 여타 분야와 개발 간 정책일관성에 대한 가장 기본적인 원칙을 제시함으로써 개발에 대한 정책일관성 및 범정부적인 접근을(whole of government approach) 독려하기 위한 수단으로 활용되고 있다. 아일랜드의 백서에서는 특히 정부 간 개발 관련 정책의 일관성을 아일랜드 원조정책의 가장 큰 우선순위로 내세울 정도로 정부 간 정책 일관성을 중시하고 있으며, 호주의 백서에서도 정부 부처 간 개발관련 정책일관성을 강조하면 서 백서나 개발정책서가 이러한 정책일관성을 이루어나가는 중요한 수단임을 강조하고 있다. 아울러, 미국의 원조 백서 또한 백서의 수립 목적을 명확한 미국의 원조 목적 및 비전을 제시 함으로써 미국 내 원조 수행기관별 또는 원조 프로그램별로 다른 목적과 방향성을 지향하는 분절화 문제를 해결하고 정책 일관성을 이루기 위함이라고 밝히고 있다. 
현재 우리의 국제개발협력 및 원조에 대한 인식의 성숙단계나, 원조 수행 체계 내에서조차 정책일관성을 이루고 있지 못한 환경 등을 고려할 때, 원조이외의 다른 분야에서의 정책일관 성까지 고려하는 것은 현실적으로 매우 어려운 일일 수는 있다. 그러나 백서가 해당국가의 개 발에 대한 인식 및 수준을 보여주고 미래지향적인 비전을 보여주는 대표적인 정책문서임을 고 려할 때, 우리나라 백서에서도 무역, 해외 투자, 이민 등 개발 관련된 정책 수립 시 개발을 고 려하는 '개발에 대한 정책 일관성(Policy Coherence for Development)' 제고 방안에 대해서 도 언급하고 방향성을 미리 정립해놓을 필요가 있을 것이다.

넷째로, 모든 공여국의 백서의 중요한 항목 중에 하나는 해당 공여국 원조의 선택과 집중 방안, 즉, 중점지원분야와 중점지원국가이다. 중점 지원 분야와 국가는 한정된 예산과 노력을 우선지원 분야와 국가에 집중할 수 있게 하는 예산 배분기준으로서의 역할을 한다. 이러한 '선 택과 집중'은 최근 원조 예산의 감소, 원조사업의 성과 및 각 공여국간의 업무분장 및 협력 등 을 강조하는 국제사회 논의 흐름에 따라 모든 공여국 및 국제기구의 핵심적인 전략이 되고 있 다. 현재 수립중인 우리나라의 원조백서에는 '선택과 집중' 전략인 중점 지원 분야 및 국가에 대한 정보가 부재하고 양자, 다자원조 실적부분만 포함되어 있어 가장 핵심적인 정책에 대한 정보가 누락되어 있으므로 방향성 위주로라도 중점지원분야와 중점지원국가 또는 지역을 백서 내용에 포함할 필요가 있다.

\section{IV. 나가며}

이상과 같이 본보고서는 타공여국의 백서 수립 목적, 내용, 수립과정 등을 살펴봄으로써 우 리나라의 원조 백서 수립에 참고할만한 시사점을 도출해보고자 하였다.

백서의 초기 수립 당시에 백서는 대부분의 공여국에서 모든 원조정책의 근간이 되는 최상위 정책문서로서의 역할을 하고 있다. 최근에는 호주, 아일랜드, 영국처럼 백서 대신에 다른 정책 서들이 실질적인 원조정책 및 사업을 가이드 하는 역할을 하고 있기는 하다. 그러나 그러한 정 책들은 급변하는 국제환경을 정책에 반영하기 위해 백서를 수정·보완하는 차원에서 수립되었 으며, 백서에서 제시하는 방향성을 여전히 따르고 있어 최상위 문서로서의 백서의 위상은 여 전한 것으로 보인다. 따라서 우리나라의 원조 백서도 국내 모든 원조정책 및 사업의 가장 기본 적인 가이드라인으로서의 역할 및 위상을 가지도록 수립되어야 할 것이다. 
아울러, 타공여국에서 백서가 탄생한 배경이나 기능을 보면 자국의 해외원조에 대한 정부

전체의 공식적인 입장을 수립하고 국민과 공유하기 위함임을 볼 수 있다. 이에 따라, 우리나라

의 백서도 내용이나 수립과정에서 원조의 필요성 및 우선순위에 대해 전 국민적으로 공감대를 이룰 수 있는 입장을 도출하고 그러한 합의된 의견이 정부의 입장으로 공식화되어 백서에 담 길 수 있는 방향으로 수립 되어야 할 것이다. 